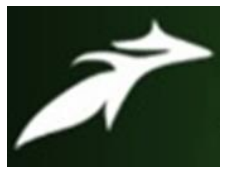

Balla Ratan Sharmila et al, International Journal of Advances in Agricultural Science \& Technology, Vol.8 Issue.11, November-2021, pg. 41-51

ISSN: 2348-1358

Impact Factor: 6.057

NAAS Rating: 3.77

\title{
PERCEPTION AND ATTITUDE OF THE FARMERS TOWARDS IMPROVED OKRA CULTIVATION PRACTICES IN EAST GODAVARI DISTRICT OF ANDHRA PRADESH
}

\author{
Balla Ratan Sharmila ${ }^{1}$; Dr. Syed H Mazhar ${ }^{2}$; Dr. Dipak Kumar Bose ${ }^{3}$; Jahanara ${ }^{4}$ \\ ${ }^{1}$ Research Scholar, Department of Agricultural Extension and Communication, SHUATS, Allahabad, Uttar Pradesh, India \\ ${ }^{2}$ Associate Professor, Department of Agricultural Extension and Communication, SHUATS, Allahabad, Uttar Pradesh, India \\ ${ }^{3}$ Associate Professor, Department of Agricultural Extension and Communication, SHUATS, Allahabad, Uttar Pradesh, India \\ ${ }^{4}$ Professor and Head, Department of Agricultural Extension and Communication, SHUATS, Allahabad, Uttar Pradesh, India \\ DOI: 10.47856/ijaast.2021.v08i11.005
}

\begin{abstract}
:
Okra (Abelmoschus esculentusL.) also known as Lady's Finger is an economically important summer vegetable crop that belongs to the family Malvaceae. It is known to have originated in tropical Africa. The crop is quite popular due to its easy cultivation, dependable yield and resistant to drought \& water logging adaptability to varying moisture conditions \& soil types. (Maurya et al., 2013). the major findings are $\mathbf{7 4 . 1 6}$ percent of the respondents have knowledge on soils that are Loose, loamy soils are required for Okra cultivation, followed by 64.16 percent of the respondents are saying that they cultivate Okra crop throughout the year. Okra plant produces fiber by 20.2 to 7.2 percent. (Chauhan 1972) East-godavari district of Andra pradesh state was selected purposively based on the maximum farmers' availability. Descriptive research design was used for the present study. A total of 120 respondents were selected purposively as a sample for the present investigation. The data was collected by using pre-tested schedule and analyzed using appropriate statistical tools. Karl Pearson's Co-efficient of Correlation test was applied to find out the association between farmers socio-economic profile with independent variables. It was concluded that the socio-economic status of the respondents constitute medium level. It was observed that majority of the respondents belonged to the high level of perception and towards improved okra cultivation practices. There was a positive and significant relationship between independent variables with dependent variables.
\end{abstract}

Keywords: Okra, farmers, perception 


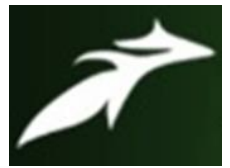

Balla Ratan Sharmila et al, International Journal of Advances in Agricultural Science \& Technology, Vol.8 Issue.11, November-2021, pg. 41-51

ISSN: 2348-1358

Impact Factor: 6.057

NAAS Rating: 3.77

\section{INTRODUCTION}

Okra (Abelmoschus esculentusL.) also known as Lady's Finger is an economically important summer vegetable crop that belongs to the family Malvaceae. It is known to have originated in tropical Africa. The crop is quite popular due to its easy cultivation, dependable yield and resistant to drought \& water logging adaptability to varying moisture conditions \& soil types. (Maurya et al., 2013) Okra fruits are used as a vegetable. The root and stem of bhendi are used for clearing the Gur or Khand or raw sugar. Its fruits with fibrous stalks are used in paper making industry. Okra leaves are used in Turkey for preparing a medicament to sooth or reduce inflammation, while ripe seeds are sometimes roasted and ground as a substitute for coffee. It is also used in soups and stews

Okra fruits are used as a vegetable. The root and stem of bhendi are used for clearing the Gur or Khand or raw sugar. Its fruits with fibrous stalks are used in paper making industry. Okra leaves are used in Turkey for preparing a medicament to sooth or reduce inflammation, while ripe seeds are sometimes roasted and ground as a substitute for coffee. It is also used in soups and stews. Okra plant produces fiber by 20.2 to 7.2 percent. Dried fruits yield 2-2.4 percent nitrogen. Mucilage of bruised seeds contains phosphoric acid, while fruits contain salts of potash, lime and magnesia (Chauhan. 1972). Appropriate in relatively low yields and quality. With increasing plant population, yield per unit area increases up to a certain limit, beyond which it decreases as resources for plant growth become limited. Further, it was reported that optimum plant population is the key element for higher yields, as plant growth and yield are affected by intra and inter row spacing. 


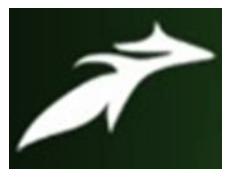

Balla Ratan Sharmila et al, International Journal of Advances in Agricultural Science \& Technology, Vol.8 Issue.11, November-2021, pg. 41-51

ISSN: 2348-1358

Impact Factor: 6.057

NAAS Rating: 3.77

\section{Objectives:-}

1. To ascertain the socio-personal characteristics of the respondents.

2. To determine the perception of the respondents towards improved cultivation practices of Okra.

\section{RESEARCH METHODOLOGY}

This section describes the approaches and methods employed for data collection and analysis. The first sub-section of this chapter presents the description of the study area. Then the details of methodology used to conduct the overall study were discussed in subsequent and subsections. Descriptive research design was used for the present study. Descriptive research design is used to describe the characteristics of a population or phenomenon being studies. East-godavari district of Andra Pradesh state was selected purposively based on the maximum farmers' availability. There were 60 mandals in in East-Godavari district out of which Yeleswaram mandal was selected purposively based on the maximum farmers availability in that area, through the help of agricultural officer. There are 13 villages in yeleswaram mandal out of those 6 villages were selected purposively based on the progressive farmers. 120 number of farmers were selected for the present study. Randomly 20 number of farmers were selected from 6 villages with the help of Village Sarpanch and Agriculture Supervisor of Respective Village (VLW, AAO \& AO) involvement in agriculture and progressive farmers. The data was collected by the researcher herself by using Primary data was collected with the help of personal interview technique, pretested structured interview schedule designed especially in the light of objectives setup for the study. The Secondary data was collected from library, journals, books, papers and the documents related to the study. The responses to the raw quantitative data coded and stored using Microsoft excel spreadsheet in order to avoid respondent anonymity. They were summarized while qualitative responses were tailed and finally prioritized in order to determine trends and patterns 


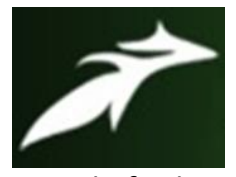

Balla Ratan Sharmila et al, International Journal of Advances in Agricultural Science \& Technology, Vol.8 Issue.11, November-2021, pg. 41-51

ISSN: 2348-1358

Impact Factor: 6.057

NAAS Rating: $\mathbf{3 . 7 7}$

in the data and draw conclusions. It was also describes, analyzed on the spot during data collection to avoid missing of relevant information.

\section{RESULTS AND DISCUSSION}

Title table -1: Socio-economic profile of the respondent.

\begin{tabular}{|c|c|c|c|c|}
\hline Sl.no & \multicolumn{2}{|c|}{ Socio economic profile of the respondent } & Frequency & Percentage \\
\hline \multirow{3}{*}{1} & \multirow{3}{*}{ Age } & Low (35 years) & 18 & 15 \\
\hline & & Medium (36-56 years) & 62 & 51.66 \\
\hline & & High (Above 56 years) & 40 & 33.33 \\
\hline \multirow{3}{*}{3} & \multirow{3}{*}{ Annual income } & Low (below 80,000) & 26 & 21.66 \\
\hline & & $\begin{array}{c}\text { Medium }(80.000- \\
1.60 .000)\end{array}$ & 57 & 47.50 \\
\hline & & High (1.60.000 above) & 37 & 30.83 \\
\hline \multirow[t]{3}{*}{4} & \multirow{3}{*}{ Land holding } & Low (0-5 acre) & 23 & 18.54 \\
\hline & & Medium (5-10 acre) & 52 & 41.93 \\
\hline & & High( above 10 acre) & 49 & 39.15 \\
\hline \multirow{5}{*}{4} & \multirow{5}{*}{ Education status } & Illiterate & 38 & 31.66 \\
\hline & & Primary & 41 & 34.16 \\
\hline & & Secondary & 29 & 24.16 \\
\hline & & Graduate \&Above & 12 & 10.00 \\
\hline & & Total & 120 & 100.00 \\
\hline \multirow[b]{2}{*}{5} & \multirow{2}{*}{$\begin{array}{c}\text { Okra } \\
\text { experience }\end{array}$} & Low (8-14) & 28 & 23.33 \\
\hline & & Medium (15-22) & 52 & 43.33 \\
\hline
\end{tabular}




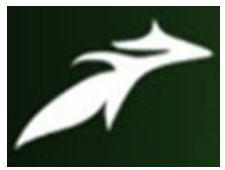

Balla Ratan Sharmila et al, International Journal of Advances in Agricultural Science \& Technology, Vol.8 Issue.11, November-2021, pg. 41-51

ISSN: 2348-1358 Impact Factor: 6.057 NAAS Rating: 3.77

\begin{tabular}{|c|c|c|c|c|}
\hline \multirow{3}{*}{6} & & High (23-29) & 40 & 33.33 \\
\hline \multirow{3}{*}{7} & \multirow{3}{*}{$\begin{array}{c}\text { Mass Media } \\
\text { Exposure }\end{array}$} & Low (4-6) & 13 & 27.5 \\
\cline { 3 - 5 } & \multirow{3}{*}{$\begin{array}{c}\text { Extension } \\
\text { contacts }\end{array}$} & Medium (10-12) & 38 & 31.66 \\
\cline { 3 - 5 } & & High (21-25) & 49 & 40.83 \\
\cline { 3 - 5 } & & Low (5-8) & 28 & 23.33 \\
\cline { 3 - 5 } & & High (12-15) & 39 & 32.00 \\
\cline { 3 - 5 } & & & 53 & 37.09 \\
\hline
\end{tabular}

\section{From the above table : 1}

It reveals that majority of respondents belonged to medium age group. This group alone constitutes 51.66per cent of the total sample.

It was evident that majority of respondent's belonged to below 4 member family size. This group alone constitutes 65.83 per cent of the total sample.

It was observed that majority of respondents belonged to the medium level of Annual Income i.e. 47.50per cent.i.e.80.000-1.60.000.

It was revealed that majority of respondent's belonged to the primary level of education i.e. 3.16 per cent.

It was evident that majority of the respondents belongs to medium level of land holding i.e. 41.93per cent farmers possessed medium amount of land holding (5-10 acres).

It was evident that majority of the respondents belongs to high level of okra farming experience i.e. 43.33per cent of the total sample. 


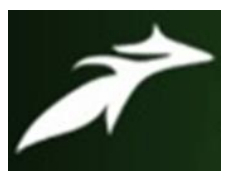

Balla Ratan Sharmila et al, International Journal of Advances in Agricultural Science \& Technology, Vol.8 Issue.11, November-2021, pg. 41-51

ISSN: 2348-1358

Impact Factor: 6.057

NAAS Rating: 3.77

It was observed that majority of farmers belonged to the high level of mass media exposure.

This group alone constitutes 40.83 per cent of the total sample.

It was revealed that majority of respondents belonged to the high level of extension contact.

This group alone constitutes 37.09per cent of the total sample.

Title table -2: Perception Of Respondents Towards Improved Cultivation Practices Of Okra

\begin{tabular}{|c|c|c|c|c|}
\hline Sl. No. & Statements & $\begin{array}{l}\text { Fully } \\
\text { correct }\end{array}$ & $\begin{array}{l}\text { Partially } \\
\text { correct }\end{array}$ & $\begin{array}{c}\text { Not } \\
\text { correct }\end{array}$ \\
\hline 1. & Loose, loamy soils are required for okra cultivation & $\begin{array}{c}89 \\
(74.16)\end{array}$ & $\begin{array}{c}19 \\
(15.83)\end{array}$ & $\begin{array}{c}12 \\
(10.00)\end{array}$ \\
\hline 2. & Cultivation of okra is possible in throughout the year & $\begin{array}{c}77 \\
(64.16)\end{array}$ & $\begin{array}{c}23 \\
(19.16)\end{array}$ & $\begin{array}{c}20 \\
(16.66)\end{array}$ \\
\hline 3. & Line sowing is require to get more yield & $\begin{array}{c}115 \\
(95.83)\end{array}$ & $\begin{array}{c}05 \\
(4.16)\end{array}$ & 0 \\
\hline 4. & $\begin{array}{l}\text { Seed rate: } \\
\text { a) } 18-22 \mathrm{~kg} \backslash \mathrm{ha} \text { (spring \&summer crop) } \\
\text { b) } 8-10 \mathrm{~kg} \text { ha (rainy season crop) }\end{array}$ & $\begin{array}{c}73 \\
(60.83)\end{array}$ & $\begin{array}{c}28 \\
(23.33)\end{array}$ & $\begin{array}{c}19 \\
(15.83)\end{array}$ \\
\hline 5. & $\begin{array}{l}\text { Half dose of } \mathrm{N} \& \text { full dose of } \mathrm{P} \& \mathrm{~K} \text { should apply at } \\
\text { the time of land preparation }\end{array}$ & $\begin{array}{c}82 \\
(68.33)\end{array}$ & $\begin{array}{c}24 \\
(20.0)\end{array}$ & $\begin{array}{c}14 \\
(11.66)\end{array}$ \\
\hline 6. & $\begin{array}{l}\text { Fertilizer and manure application is needed at the } \\
\text { time of land preparation, sowing, flower and fruit } \\
\text { formation }\end{array}$ & $\begin{array}{c}68 \\
(56.66)\end{array}$ & $\begin{array}{c}36 \\
(30.00)\end{array}$ & $\begin{array}{c}16 \\
(13.33)\end{array}$ \\
\hline 7. & $\begin{array}{l}\text { Irrigation is important during flowering \& fruiting } \\
\text { stage }\end{array}$ & $\begin{array}{c}83 \\
(69.16)\end{array}$ & $\begin{array}{c}23 \\
(19.16)\end{array}$ & $\begin{array}{c}14 \\
(11.66)\end{array}$ \\
\hline
\end{tabular}




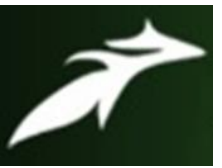

Balla Ratan Sharmila et al, International Journal of Advances in Agricultural Science \& Technology, Vol.8 Issue.11, November-2021, pg. 41-51

ISSN: 2348-1358

Impact Factor: 6.057

NAAS Rating: 3.77

\begin{tabular}{|c|l|c|c|c|}
\hline 8. & $\begin{array}{l}\text { Mulching is necessary to minimize weed \& } \\
\text { moisture loss }\end{array}$ & $\begin{array}{c}89 \\
(74.16)\end{array}$ & $\begin{array}{c}19 \\
(15.83)\end{array}$ & $\begin{array}{c}12 \\
(10.00)\end{array}$ \\
\hline 9. & $\begin{array}{l}\text { IPM,IDM are necessary to control pest \& disease } \\
\text { attack }\end{array}$ & $\begin{array}{c}79 \\
(65.83)\end{array}$ & $\begin{array}{c}23 \\
(19.16)\end{array}$ & $\begin{array}{c}18 \\
(15.00)\end{array}$ \\
\hline 10. & $\begin{array}{l}\text { Growth regulator are necessary to increase the } \\
\text { yield \& quality }\end{array}$ & $\begin{array}{c}66 \\
(55.00)\end{array}$ & $\begin{array}{c}37 \\
(30.83)\end{array}$ & $\begin{array}{c}17 \\
(14.16)\end{array}$ \\
\hline
\end{tabular}

From the table-2. The results described as followed:

From the table-2. the major findings are 74.16 percent of the respondents have knowledge on soils that are Loose, loamy soils are required for Okra cultivation, followed by 64.16 percent of the respondents are saying that they cultivate Okra crop throughout the year, followed by 95.83 percent of the respondents have maintaining Dibbling method to sow the seeds, it means sowing is also done by dropping the seeds behind the plough furrow in line sowing, followed by 60.83 percent of the respondents have knowledge on seed rate $18-22 \mathrm{~kg} / \mathrm{ha}$ during (spring and summer crop) and 8-10 kg/ha during (rainy season), followed by 68.33 percent of the respondents have knowledge on application of NPK that should apply at the time of land preparation, followed by 56.66 percent of the respondents have knowledge on application of fertilizer and manure application at the time of land preparation, sowing, flowering and fruit formation stages, followed by 69.16 percent of the respondents having knowledge on irrigation application at critical stages - light irrigation is given soon after seed sowing to ensure good germination. The crop is irrigated at an interval of 4-5 days in summer. Normally the crop is irrigated by adopting the furrow method, followed by 74.16 percent of the respondents are using mulching to minimize weed and moisture loss, followed by 65.83 percent of the respondents have knowledge on using IPM, IDM practices to control pest and diseases attack, followed by 55.00 percent of the respondents are having knowledge on growth regulators to 


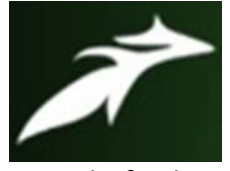

Balla Ratan Sharmila et al, International Journal of Advances in Agricultural Science \& Technology, Vol.8 Issue.11, November-2021, pg. 41-51

ISSN: 2348-1358 Impact Factor: 6.057 NAAS Rating: 3.77

increase the yield and quality. All these process will take 50-65 days to harvest, the pods are ready to harvest.

Table -3 Distribution of respondents according to their perception level of improved okra cultivation practices.

\begin{tabular}{|c|c|c|c|}
\hline \multirow{2}{*}{ Sl.no. } & \multirow{2}{*}{ Perception of the respondents } & \multicolumn{2}{|c|}{ Response } \\
\cline { 3 - 4 } & Frequency & Percentage \\
\hline $\mathbf{1}$ & Low (7-12) & 20 & 16.66 \\
\hline $\mathbf{2}$ & Medium (13-16) & 36 & 30.00 \\
\hline $\mathbf{3}$ & High (17-20) & 64 & 53.33 \\
\hline & Total & $\mathbf{1 2 0}$ & $\mathbf{1 0 0 . 0 0}$ \\
\hline
\end{tabular}

The data presented in the table reveals that 53.33per cent of the respondents belongs to the high level of perception categories followed by 30.00per cent of the respondents belonged to the medium level and similarly 16.66per cent of the respondents are belongs to the low level of perception. 


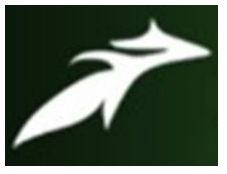

Balla Ratan Sharmila et al, International Journal of Advances in Agricultural Science \& Technology, Vol.8 Issue.11, November-2021, pg. 41-51

\section{Percentage}

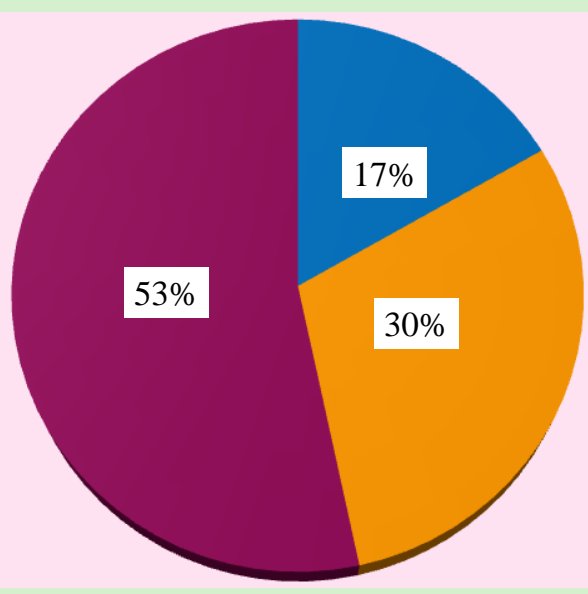

- $\operatorname{LOW}(7-12)$

$\square \operatorname{MEDIUM(13-16}$

- HIGH(17-20)

Fig -1 Distribution of respondents according to their perception level of improved okra cultivation practices

Table -4 Relationship between independent variable and perception of farmers towards improved okra cultivation practices. .

\begin{tabular}{|c|c|c|}
\hline SL No. & Variables & $\begin{array}{c}\text { ' } \mathbf{r} \text { ' value for } \\
\text { perception }\end{array}$ \\
\hline 1 & Age & 0.360 \\
\hline 2 & Income & 0.201 \\
\hline 3 & Land holding & 0.700 \\
\hline 4 & Educational status & 0.322 \\
\hline
\end{tabular}




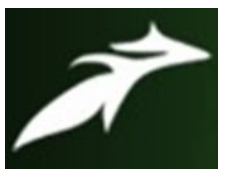

Balla Ratan Sharmila et al, International Journal of Advances in Agricultural Science \& Technology, Vol.8 Issue.11, November-2021, pg. 41-51

ISSN: 2348-1358

Impact Factor: 6.057

NAAS Rating: 3.77

\begin{tabular}{|c|c|c|}
\hline 5 & Okra experience & 0.360 \\
\hline 6 & Mass media exposure & 0.998 \\
\hline 7 & Extension contacts & 0.941 \\
\hline 8 & Economic motivation & 0.998 \\
\hline
\end{tabular}

\section{* Significant at the 0.01 level of probability. ** Significant at the 0.05 level of probability. NS= non-significant.}

From the above table-4. Revealed that the independent variables i.e. age, income, land holding, educational status, okra experience, mass-media exposure and extension contacts, and economic motivation with perception and attitude of respondents are positively significant at $0.01 \%$ probability there was a positive relationship between the independent variables with dependent variable.

\section{CONCLUSION}

It was concluded that the socio-economic status of the respondents constitute medium level. It was observed that majority of the respondents belonged to the high level of perception regarding he improved okra cultivation practices.. There was a positive relationship between independent variables with dependent variables i.e. perception of the respondents. 


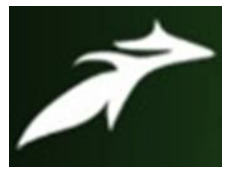

Balla Ratan Sharmila et al, International Journal of Advances in Agricultural Science \& Technology, Vol.8 Issue.11, November-2021, pg. 41-51

ISSN: 2348-1358

Impact Factor: 6.057

NAAS Rating: 3.77

\section{REFERENCES}

[1]. Adesuyi, A.A., Longinus, N.K., Olatund A.M., Chinedu, N.V. (2018). Pesticides related knowledge, attitude and safety practices among small-scale vegetable farmers in lagoon wetlands, Lagos, Nigeria, Journal of Agriculture and Environment for International Development. Vol.112 (1):81-99.

[2]. Choudhury, A.R., Mondal, F., Ahasan, U.K., Hossain,S., Azad, O.K., Mohammad, D.H.P., Uddain, J., Mohammed, S.R., Ahmed, N., Choi, K.Y., and Naznin, M.T. (2021). Evaluation of Biological Approaches for Controlling Shoot and Fruit Borer (Eariasvitella F.) of Okra Grown in Peri-Urban Area in Bangladesh, Horticulture. Vol.7 (7).

[3]. Kumar, S., Dagnoko, S., Haougui,A., Alain, R., Dov, P., and Kouame, C. (2010). Okra (Abelmoschus spp.) in West and Central Africa: Potential and progress on its improvement. African Journal of Agricultural Research. Vol. 5 (25) : 3590-3598.

[4]. Maurya, R.P., Bailey. A. Jamar., Chandler.A.Jeff St. (2013). Impact of plant spacing and picking interval on the growth, fruit quality and yield of Okra (Abelmoschus esculentus (L.) Moench). American journal of Agriculture and Forestry,2013, 1(4) 4854.

[5]. Pushpavalli, R., Arulthasan,T., Kandaswamy, K.G. (2014). Growth, nutrient uptake an yield of Okra (Abelmoschusesculentus (L) Moench) as influenced by organic and inorganic fertilizers. Academia Journal of Agricultural Research.Vol.2 (10): 203-206.

[6]. Sood, R. and Kaur, R. (2019). Effect of Sowing Time on Performance of Okra [Abelmoschusesculentus (L.) Moench] Varieties under Jalandhar Conditions Int.J.Curr.Microbiol.App.Sci 8(12): 568-576. 